\title{
Strategic Communication with the Islamic World
}

\author{
Marty Z. Khan *
}

\section{Introduction}

Nation-states (particularly non-Muslim states) will face daunting challenges in the struggle against terrorists who use Islam as a justification for their actions. This form of terrorism is multidimensional and global, and it is likely that this struggle will span several generations. While Muslim states are also victims of terrorism, non-Muslim states are at a greater disadvantage, even if they do have constitutional protections of religion for all citizens, including Muslims. In this continuing struggle, non-Muslim states must persuasively communicate with the Islamic world about their aims and what they hope to achieve in the war against terror. Considering the scope of the violence that has already been perpetrated by these kinds of terrorists, countries engaged in this struggle will have to be extraordinarily vigilant to protect their interests, and in some cases, their allies. In contrast to this, terrorist organizations will continue to use their networks to counteract those governments that they are against and portray them negatively. Despite the threats posed by terror groups and the challenges to conducting military operations against irregular actors such as terrorists, non-Muslim states must prevail in their mission. ${ }^{1}$

This article explores some alternatives that may enhance the capabilities of strategic communication as a viable instrument of warfare. ${ }^{2}$

\section{Terrorists’ Communication Strategy: Their Center of Gravity}

After almost ten years in the global war on terror, non-Muslim states will have to enhance awareness among Muslims in the Islamic World of their objectives. Eliminating these terrorists is difficult, if not impossible, because of the financial and moral support they receive from some segments of Muslim communities throughout the world. In essence, this support comes through their manipulative exhortation that the war against terror-a war directed at very specific actors - is a war against all of Islam.

Their communication strategy is clearly effective. They are achieving their objectives through their ability to gain financial and other support from Muslim communities. It is likely this will continue to pose major challenges for non-Muslim countries' policy makers. One tactic that might considerably weaken terrorists' capabilities is to use their

* Marty Z. Khan is a colonel in the U.S. Air Force Reserve and works with NATO as a civilian. Acknowledgement of thanks to Lieutenant Commander Raja Hussain, Drs. David Gosling, Alton Grun, Stanley Puckett, and Aline Stomfay-Stitz for reading earlier drafts.

1 It is crucial to break the cycle of deprivation in much of the Muslim world that lends terrorist groups much of their appeal. Little boys in the Islamic World will live a life similar to their parents, with very few or no opportunities, as their lives will be susceptible to the ravages of poverty and vulnerable to recruitment by terrorist organizations.

2 Raja G. Hussain, "BADAL: A Culture of Revenge - The Impact of Collateral Damage on Taliban Insurgency," M.A. thesis (Monterey, CA: Naval Postgraduate School, 2008), 40-46. 
communication strategy, which focuses on Islam - the center of gravity for their power-to undermine the religious link to their communities. This approach is within non-Muslim countries' capacity, and thus it should be considered as nations outside of the Muslim community continue to seek ways to increase the effectiveness of their messages to the Islamic World.

No group has the sole authority to speak for its entire religion, and Islam is no exception. Given that over 23 percent of the world's population is Muslim, it is impossible that any one group would be able to articulate a message that would be accepted by all Muslims around the globe. ${ }^{3}$ Nonetheless, Islamist terrorists continue to include Islamic references, themes, and traditions as justifications for their actions. Knowledge of Islam may gain one a certain degree of legitimate authority, but purposeful misinterpretation of the Quran and other holy texts is without doubt un-Islamic. It is obvious that those who misuse Islam's religious principles are not seeking spirituality, but rather seeking their own power and gain. The slant that terrorists put on Islam in order to achieve their ends does matter, especially when it goes against most Muslims' sensitivities about their religious beliefs and meaningful interpretations of the Quran. What really matters is to point out such groups' inaccurate usage of Islamic themes and their purposeful denigration of Islam. For instance, if a group were to inaccurately communicate religious themes for its benefit, then anyone would have the right to question the basis for such interpretations and the hatred they promote. Indeed, this right to question such inaccurate interpretations of the Quran is not reserved exclusively for Muslims. Anyone and everyone has this right to ensure that the disparagement of Islam is not perpetrated by religious zealots in the name of hate. This is the weakest part of the terrorists' communication strategy. Considering the stakes ahead, non-Muslim countries must exploit every aspect of it. However, they must tread with the utmost care and respect in order to avoid creating further moral or ethical dilemmas, and they must speak in such a way that terrorists cannot twist into an 'attack' on Islam. At the same time, however, this approach must not be viewed as gratuitous.

A communication strategy with the Muslim world must be a key policy component of a successful prosecution of the war on terror. The focus must be to weaken the terrorists' community support, confidence in their status as spokesmen for Islam, and the legitimate authority they seem to project. Because extremists have primarily relied on Islamic themes to spread their messages, non-Muslim countries, too, must likewise spread their own messages, which are rooted in universal respect for all religions. This is likely to gain some degree of acceptance among moderate Muslims. Respectful usage of religious themes can be an effective tool in chipping away at the absolute authority terrorists gain through the use of persuasive religious sanctions as moral underpinnings for their attacks. It is, therefore, consequential that defeating terrorist organizations that rely on Islam as a justification for their acts will require a strategy that is focused on Islamic

3 See "Mapping the Global Muslim Population," Pew Forum on Religion and Public Life (7 October 2009); available at http://pewforum.org/Muslim/Mapping-the-Global-MuslimPopulation.aspx. 
principles to undermine the terrorists' credibility and accepted moral authority in the semi-illiterate societies in which they prosper.

The Islamic world is not a homogenous entity, and encompasses a wide range of cultural, ethnic, and linguistic diversity, stretching generally from Nigeria to Morocco to the Philippines and Indonesia. Muslims, however, will always identify with basic universal themes about their religion; namely, the expectation of respect and their own unquestionable devotion to Islam. These two themes, which are shared by all Muslims, cannot be overemphasized. Terrorists will continue to exploit these two themes to their advantage by taking positions that contradict basic scholarly and generally accepted interpretations of what mainstream Islam is and what it should be. Thus, when crafting a communication strategy, these themes must be deliberately taken into account. Such an approach will help to shape Muslims' opinions on why non-Muslim nations are at war with terrorists in their respective states or geographic territories, and will help bolster the message that such wars are not wars against Islam.

Strategically, the focus must be on terrorists' inaccurate usage of Islam as a tool for promoting and/or sustaining their activities. After having identified terrorists' successes as being linked to their interpretative versions of Islam, which often contradict mainstream Islamic laws and practices, it is then necessary to exploit them via a communication strategy. A strategy to undermine their credibility in the Islamic world could have profound consequences in revealing their (mis)-interpretation of Islam as contrary to Islam and its values of mercy and compassion. It is evident that extremists' exploitation of Islam is a key basis for their claims - essentially, they believe that they have a religious sanction for the horrendous acts they commit.

The ongoing debate about the utility of strategic communication would not be complete without highlighting other factors that enhance the credibility of the terrorists' ideology. Factors such as poverty, illiteracy, corruption, and lack of opportunity breed terrorism. Indeed, in the Islamic World, it is an incontrovertible fact that these conditions are pervasive. While most Muslim countries have cordial relations with non-Muslim countries, terrorists have exploited these links to claim that the root cause for Muslims' problems is Western support for corrupt and autocratic governments in the Islamic world. Correspondingly, terrorists have established charitable organizations that have successfully exploited poor socio-economic conditions to their advantage by providing food, shelter, schooling, and other scarce resources to those in need. Along with the goodwill terrorists receive from such activities, they have outmaneuvered most Muslim governments to provide effective services for their impoverished citizens, in some places effectively serving as the state themselves. As a result, they have gained increased stature and respect among Muslims throughout the world from all socio-economic and educational levels. For example, after the monsoon floods that devastated Pakistan during the summer of 2010, militant organizations established humanitarian camps to help those impacted. Lashkar-e-Taiba (LeT), for example - the group behind the terrorist attacks in Mumbai, India in 2008 - established such camps to help people in need, and 
apparently operated without any governmental interference or restrictions. ${ }^{4}$ Despite the LeT's reputation as a militant organization, its social programs are seen by poor Pakistanis as consistent with Islamic traditions of compassion and the importance of helping those in need. In this case and in others, radical Islamist organizations exploit this expectation to provide charity to their advantage, and through these efforts they continue to deepen their links to Muslim communities.

\section{Possible Strategy}

Much of the literature on communication has focused on the definition of strategic communication: what it is (and what it is not), what it should be, and the challenges of implementing an effective program. Yet with all that has been written on strategic communication, non-Muslim countries continue to face major challenges in getting their messages across to their intended audience. Considering these issues, is it possible that non-Muslim countries will continue to encounter problems in communicating their messages to the Muslim world? Assuming this is true, is there something that can be done to minimize the problems? While it may be impossible to design an effective program for an organization as complex as the U.S. Department of Defense (DoD) to implement, providing guidelines and standards for steering military and civilian personnel might be a potential solution. As a way forward, it is imperative to analyze the two periods of time in which the United States was pulled into the Islamic world to address issues similar to the challenges the DoD faces today.

\section{Historical Context: The United States' Pursuit of the Barbary Pirates}

From a historical perspective, the first U.S. military and diplomatic engagement with the Muslim world was connected with pirates operating on the fringes of the Ottoman Empire almost two hundred years ago. Key U.S. government officials, including presidents, were actively occupied with addressing the nagging threat of pirates preying on commercial shipping near what is today Algeria, Libya, Morocco, and Tunisia. Pirates captured U.S. ships, enslaved the crews, and demanded payments from the U.S. government for their release. The U.S. government negotiated with the pirates' representatives and complied with most of their demands in hopes of saving American lives and restoring their sailors to their status as free men. While the Muslim pirates conducted their activities primarily to enrich themselves, they used their religion as an ideological justification to attack shipping from Christian countries. Distinguished U.S. figures such as John Adams, Thomas Jefferson, John Madison, and James Monroe were all, to some degree, engaged to end the piracy, which severely threatened U.S. commercial activities. ${ }^{5}$ Eventu-

4 Jim Sciutto, "Militants Moving in Behind Pakistan Flood Waters," ABC News (18 August 2010), available at http://abcnews.go.com/International/militants-moving-pakistan-floodwaters/story?id=11427597.

5 Jefferson, unsurprisingly, showed the greatest intellectual curiosity about Islam. He ordered a copy of the Quran from a London bookseller, and appears to have studied it carefully. Jefferson's copy of the Quran is currently held at the Library of Congress in Washington, D.C. 
ally, fighting the pirates in the Barbary States evolved into a national strategic priority. While there were disagreements between political leaders in the U.S. on how to solve this problem, they nevertheless were convinced that the pirates posed a mortal threat to the commercial activities of the young nation, which had only recently emerged from its violent split from the British Empire. Diplomatic engagements between the United States' and the pirates' representatives in North Africa to end the attacks resulted in several treaties during the period from 1786 to 1836 , a set of agreements that are collectively known as the Barbary Treaties. In a possible effort to resolve any misunderstanding related to Islam, Article 11 of the Treaty of Peace and Friendship between the United States of America and the Bey and Subjects of Tripoli of Barbary, signed on 4 November 1796, noted that:

As the government of the United States of America is not in any sense founded on the Christian Religion, as it has in itself no character of enmity against the laws, religion or tranquility of Musselmen [Muslims], and as the said States never have entered into any war or act of hostility against any Mahometan [Muslim] nation, it is declared by the parties that no pretext arising from religious opinions shall ever produce an interruption of the harmony existing between the two countries. ${ }^{6}$

Similarly, in another treaty with Tripoli, known as the Treaty of Peace and Amity, signed in Tripoli on 4 June 1805, issues of religion are noted in Article 14:

As the Government of the United States of America, has in itself no character of enmity against the Laws, Religion or Tranquility of Musselmen [Muslims], and as the said States never have entered into any voluntary war or act of hostility against any Mahometan [Muslim] Nation, except in the defence of their just rights to freely navigate the High Seas: It is declared by the contracting parties that no pretext arising from Religious Opinions, shall ever produce an interruption of the Harmony existing between the two Nations; And the Consuls and Agents of both Nations respectively, shall have liberty to exercise his Religion in his own house; all slaves of the same Religion shall not be Impeded in going to said Consuls house at hours of Prayer. ${ }^{7}$

While the primary goal of the United States was to end Barbary attacks on American ships, the treaties also highlighted the fact that religion was drawn into the negotiations because of its importance to the pirates. The inclusion of religion in a treaty between states was a likely compromise by U.S. negotiators to persuade the pirates that the United States would respect Islam, and that their activities would not be linked to their religion. The narrative drawn from these documents emphasizes the importance of both reason and religious themes in the preparation of the treaties. The Muslims' piety and devotion to Islam were indisputable facts (which is not to say that piety and devotion on the part of Christian negotiators were not also important) that were seen as exerting a significant influence on certain aspects of policy making.

6 Full text of the treaty is available at http://avalon.law.yale.edu/18th_century/bar1796t.asp\#t2.

7 Full text of the treaty is available at http://avalon.law.yale.edu/19th_century/bar1805t.asp. 


\section{The Fall of the Shah of Iran: Proliferation of Islamist Extremists}

The end of the Barbary Pirates' attacks on U.S. commercial shipping resulted in over 175 years of peace between the U.S. and the Islamic world, from the dissolution of the Ottoman Empire to the emergence of independent Muslim states. However, after the Shah of Iran - the leader of a repressive and corrupt regime that had been propped up by successive administrations in Washington-was forced to flee his country on 16 January 1979, Ayatollah Ruhollah Khomeini, Iran's most influential religious leader, inspired radical groups and individuals throughout the world to use Islam as an ideology to get the political change they desired.

Ayatollah Khomeini's regime was also repressive and corrupt, but he had the support of the masses, who wanted to rid Iran of the vestiges of the Shah's excesses. Khomeini's religious exhortation and the intermixing of politics and religion influenced many young men around the Middle East and brought the issue of Islamic radicalism to the attention of global media outlets.

From January 1979 to 2001, the frequency and level of U.S. engagement with the Islamic world increased. However, terrorist attacks on U.S. interests and facilities overseas soon began to increase (e.g., terrorist attacks on the U.S. Marines barracks in Beirut in 1983; military housing in Saudi Arabia; the U.S. Embassy in Nairobi, Kenya in 1998; and the U.S. Navy destroyer USS Cole in port in Yemen in 2000). But it was the attacks of 11 September 2001 on New York City and Washington D.C. that pushed the U.S. to partner with its allies to conduct military operations to capture those who had masterminded the attacks. Hence, from the September 2001 attacks to the current military operations in Afghanistan, the need to effectively communicate with the Islamic world has become a national priority of strategic importance.

From the overthrow of the Shah of Iran to the 9/11 attacks, U.S. presidents and officials have repeatedly asserted that the United States is not at war with Islam. Other nonMuslim nations have followed suit with the same strategy. Despite non-Muslim countries' sincerity and generosity in offering help to poor Muslims worldwide, terrorist organizations have succeeded in disseminating their messages throughout the Islamic world. As a result, the search for a communications model to counteract terrorists' methodologies has picked up pace. The challenges of designing an effective model were noted by a senior DoD civilian official and general officers in their speeches to the Air War College Class of $2008 .^{8}$ One official, for example, stated that it is crucial to get communications with the Islamic world right, but there are monumental problems in the effort to get through to a broad cultural milieu in which the U.S. is seen negatively. The speakers were correct about the challenges, which included language, illiteracy, government-controlled media (with a bias against non-Muslim countries), the lack of access to communication resources among the general population (e.g. radios, TV, newspapers), religious leaders' open criticism of non-Muslims, and terrorists' exploitation of

8 The Air War College (the United States Air Force's premier senior educational institution for lieutenant colonels) distinguished leaders' lecture program is intended for non-attribution. As a result, the names of these officials will not be identified. 
stories dealing with collateral damage (whether real or not). Considering all the challenges inherent in relaying messages to such a broad audience, an inflexible communications model is not practical. A one-size-fits-all approach will not work, and the DoD understands this. What is more practical are guidelines for communication, which all DoD personnel (especially military personnel with direct contact with Muslims) can follow when constructing their messages. These guidelines can also form the basis for oral communication (interviews) that protect the United States' image and explain its objectives, while at the same time showing respect for Islam.

\section{Admiral James Stavridis' Strategic Communication Guidelines}

Admiral James G. Stavridis, in his Joint Force Quarterly article, "Strategic Communication and National Security" explored the issue of communication to diverse audiences within the U.S. Southern Command's geographical area of responsibility. ${ }^{9}$ His articulation of the challenges the Southern Command faces is indicative of what all U.S. organizations face in communicating with the Islamic world. Theadmiral's article was insightful because it is one of the few statements from a U.S. official to offer some specific and extremely valuable guidelines on communicating with cultures different from the U.S.

The two most important guidelines Admiral Stavridis recommended that could be applied to communicating with the Islamic world are:

- Tell the truth

- Understand your audience.

As with all communication efforts, telling the truth is of paramount importance because it establishes credibility with the targeted audience and increases the expectation that the truth will be told. Telling the truth must be the overriding principle in all communication, regardless of the circumstances. Understanding the Islamic world is critical, especially where a vast range of differing points of view on the meaning of Islam and the role of the individual in thinking critically about religion complicate the process of communicating with Muslims. In the Islamic world, the lack of emphasis on individualism leads to peer pressure and group-think, and when such conditions are present, the process of communication is further complicated.

Building on Admiral Stravridis' communication guidelines, non-Muslim countries can go one step further to refine their strategy to undermine terrorists' communication strategy with their Muslim audiences. A new focused direction of interactions with Muslims in the Islamic world is necessary to dispel their belief that the war on terror is a war on Islam. To assuage Muslims' concerns and undermine the terrorists' ability to use Islam as a tool, the rest of this section will offer some suggestions for consideration.

9 Admiral James G. Stavridis, "Strategic Communication and National Security," Joint Force Quarterly 46 (2007): 4-7. 


\section{Avoid Islamic Labels}

Avoid using the term "Islamic terrorists" in all communication. Muslims see the usage of Islamic themes as a linkage of terrorism to their religion and, furthermore, as a denigration of their religion, which they vehemently abhor and resent. However, there is an exception. When, for example, a terrorist organization uses Islam in their name (such as the group "Palestinian Islamic Jihad"), saying "Islamic Jihadists conducted an attack on innocent civilians that disparages Islam" is legitimate. The rationale for this is that, when a group uses Islam in their name, they want to project they have an Islamic identity and show that they operate under distinct Islamic rules. That linkage must be exploited, but with care, so as not belittle Islam in the message. On the other hand, when terrorists do not use Islam in their name but use it as an ideology, it would be justifiable to say, "terrorists who use Islam as ideology conducted an attack on innocent civilians." Though such a message is rather long and cumbersome, it is more accurate, and more likely to be acceptable to Muslims. Using this approach will help to illustrate how terrorists have disgraced Islam and avoid the linkage of Islam to terrorism.

\section{Tell the Truth}

As Admiral Stavridis noted in his article, telling the truth matters. Communication with Muslims must constantly be rooted in the theme "tell the truth," and it must be the foundation of all messages. Such a position will increase credibility and illustrate the differences between non-Muslim countries and terrorist organizations' messages. During the Cold War, the British Broadcasting Corporation (BBC), Radio Free Europe, and the Voice of America set very high standards on telling the truth. Throughout the world and especially behind the Iron Curtain, there was widespread enthusiasm for news from these media outlets because of the perception that the truth was being broadcast. ${ }^{10}$ In the Islamic world, interpretation and point of view will be the basis of differences between messages, but in the long run, non-Muslim countries' messages could potentially influence both ordinary and elite Muslims. Over time, it is highly likely that the expectation to be told the truth will increase among Muslim audiences. This, however, will take time, and time matters when building credibility with a community. Past approaches have led to notions of mistrust of the West by Muslims, even though it was major nonMuslim countries that took the lead in conducting military operations to help free millions of Muslims from oppression, such as Bosnians, Kosovar Albanians, and Kuwaitis.

10 See Arch Puddington, Broadcasting Freedom: The Cold War Triumph of Radio Free Europe and Radio Liberty (Lexington, KY: University of Kentucky Press, 2000); James L. Tyson, U.S. International Broadcasting and National Security (New York: Ramapo Press, 1983); and Sig Mickelson, America's Other Voice: The Story of Radio Free Europe and Radio Liberty (New York: Praeger, 1983). 


\section{Use Islamic Themes and Principles}

Terrorists (and Muslims in general) do not have an absolute monopoly on the use of Islamic themes and principles in their messages. Issues such as suicide attacks, improvised explosive devices (IEDs), killing innocent people, illegal activities, and violence towards women are potential areas for exploitation. The Quran and Hadith (the documented sayings and deeds of the Prophet Muhammad ${ }^{11}$ ) are the primary basis for Islamic law, and when terrorist organizations cite these sources, it is likely their interpretations are not consistent with respected scholarly interpretations. For all intents and purposes, they skillfully craft their messages with their religious interpretation to fit their ideology. As a result, their credibility could be exploited on such issues with the appropriate Quran and Hadith references. Here are four examples to use a framework to build or refine a strategy to communicate with the Islamic world:

Commonality of People. There is an agreed commonality between Christians, Jews, and Muslims, who are often referred to collectively as the "People of the Book." (In the Quran, there are numerous references to Abraham, Moses, Mary (Jesus' mother), and Jesus Christ, and all are held in high esteem in Islam). It is noted in Surah 17:70, in a chapter titled "The Children of Israel," that "Verily, we have honored the children of Adam. We carry them on the land and the sea, and have made provision of good things for them, and have preferred them above many of these whom we created from a marked preferment. We have honored the sons of Adam." This verse can be used to show the bond between all people, irrespective of religion, through their common lineage being traced back to Adam. While Muslims have recognized Christians and Jews as people of the Book and children of Adam, this honor must be extended to all peoples of all religions, within the traditions and customs of Islam.

Importance of Education. When Muhammad was asleep while on a retreat, he was awakened by a voice that commanded him, "Read!" He opened his eyes and saw the Angel Gabriel, who commanded him again to read. Muhammad said he could not read, and the Angel Gabriel informed him he was chosen as the Prophet of God to spread His message. This event is significant in Islam, and it has been interpreted to show the importance of education for everyone, without any distinctions of gender or station. ${ }^{12}$

Suicide and Suicide Attacks. Suicide is strictly forbidden in Islam. One Islamic scholar concluded in his article, "Suicide Attacks and Islamic Law," that even in wartime suicide attacks and the intentional targeting and killing of women, children, and civilians are prohibited in Islam. ${ }^{13}$ While he cited some scholarly references and Islamic

11 In Islam, it is a general practice to say Peace and Blessings be Upon Him (abbreviated, PBUH) when making a direct reference to Prophet Muhammad. This respect is accorded in this article.

12 Muhammad Marmaduke Pickthall, The Meaning of the Glorious Qur'ān: Text and Explanatory Translation (Mecca, Saudi Arabia: Muslim World League, 1977), iv-v.

13 Muhammad Munir, "Suicide Attacks and Islamic Law," International Review of the Red Cross 39:869 (March 2008): 88-89. 
law to support his conclusion, he also cited others who claim that suicide attacks are justified. The scholar's principal citation to support his conclusion is what the Prophet Muhammad (PBUH) is reported to have said, as noted in the Hadith, "None amongst you should make a request for death, and do not call for it before it comes, for when any of you dies, he ceases [to do good] deeds and the life of the believer is not prolonged but for goodness." ${ }^{14}$ As a result, the issues relating to suicide and suicide attacks are very divisive. Some influential Muslim scholars have stated the attacks are justified, in spite of the Quranic proscriptions.

Status of Women and Women's Education. The Prophet Muhammad's first wife, Khadija, was a wealthy businesswoman, who engaged in trade inside and outside of the Arabian Peninsula. She offered him the position to operate her business because of his honesty, and at the age of twenty-five he married her (she was fifteen years his senior). ${ }^{15}$ The right of women to work is noted in Surah 4:32, which states: "And covet not the thing in which Allah hath made some of you excel others. Unto men a fortune from that which they earned, and unto women a fortune from that which they have earned. (Envy not one another) but ask Allah of His bounty. Lo! Allah is Knower of all things."

Use Muslims in Uniform as Communicators to the Islamic World. Where appropriate, Muslims in uniform should support key commands and general officers to communicate with the Islamic world. Many Muslims are serving patriotically in the armed forces of numerous non-Muslim countries. However, a few have committed horrendous acts of violence against their fellow servicemen, as was the case in shooting at the U.S. military base at Fort Hood, Texas, in 2009. Despite the few who have betrayed the trust placed in them by their families, their colleagues, their respective branches of service, and their country, those Muslim servicemen who are still serving with honor should be given the opportunity to play an active role in an overall strategy to communicate with the Islamic world. While general officers should always speak for themselves, selected lower-ranking servicemen and women can play an extremely valuable role. Non-Muslim countries must take full advantage of this valuable resource. Such usage will showcase the strength of a country's ethnic diversity, acceptance of its Muslim citizens, and more importantly, project a point of view that respects the sanctity of all religions, including Islam.

\section{Concluding Remarks}

The fight against terrorists who use Islam as a justification for violence will require innovative methods to adapt to changing situations, of which communication is a critical factor. Though the Islamic world is not homogenous, Muslims do hold some generally shared attitudes regarding their faith. This is an area that could offer potential benefits, if properly exploited. Non-Muslim countries' strategic communication with the Islamic

\footnotetext{
14 Ibid., 79. In Muslim Ibn Al-Hajjaj, Saheed Muslim, Dar Ehya Al-Turath Al-Arabi, 1955, Vol. 4, p. 2065, Hadith no. 2682.

15 Fazlur Rahman, Islam (Chicago: University of Chicago Press, 1979), 11.
} 
world will require extreme sensitivity in order to avoid showing disrespect to the religion. While Muslims may have a general right to interpret their religion and communicate that interpretation to the world, this right is not absolute. Others, including non-Muslims, have this right as well, although obviously within the realm of respecting Muslims' sensitivities and the sanctity of the Quran. As such, terrorists who use Islam as a justification for conducting heinous attacks should be publicly criticized to show how their actions disparage Islam. Non-Muslim countries have at their disposal resources (money and Muslims in uniform) to counter terrorist organizations' communication strategies of using Islam to sanction their attacks. While the war against terrorists who use Islam as an ideology may continue for decades, now is the time to disrupt their center of gravity to significantly undermine their credibility among the very Muslim communities in which they thrive. 
THE QUARTERLY JOURNAL

\section{Bibliography}

Munir, Muhammad. "Suicide Attacks and Islamic Law." International Review of the Red Cross (2008): 39:869 ..

Puddington, Arch. Broadcasting Freedom: The Cold War Triumph of Radio Free Europe and Radio Liberty . Lexington, KY: University of Kentucky Press, 2000.

Stavridis, James G.. "Strategic Communication and National Security." Joint Force Quarterly 46 (2007). 